\title{
$\mathrm{GPS}$ 예측궤도력을 이용한 정밀단독측위 정확도 분석
}

\section{Accuracy Analysis of Precise Point Positioning Using Predicted GPS Satellite Orbits}

\author{
하지현 ${ }^{*}$, 허문범 ${ }^{*}$, 남기욱* \\ Ji-Hyun $\mathrm{Ha}^{*}$, Moon-Beom Heo* and Gi-Wook Nam
}

요 약

본 논문에서는 IGS 예측궤도력을 이용한 준실시간 정밀단독측위 위치추정 정확도를 분석하였다. 그 결과 2010년 1년 동안 평균오차 1 1.6cm, 표준편차 1 1.3cm로 신속궤도력과 유사한 정밀도 달성이 가능했다. 궤도 이상이 나타난 날 중 $44 \%$ 에서 $10 \mathrm{~cm}$ 이상의 좌표오차가 관측되었으며, 최대 $1.7 \mathrm{~km}$, 평균오차 최대 $308 \mathrm{~m}$ 수준으 로 나타났다. 따라서 예측궤도력을 활용 시 사전에 궤도력 이상현상에 대한 점검이 반드시 필요할 것으로 판단 된다.

Abstract

In this paper, near-real-time positioning accuracies of precise point positioning technique were analyzed using IGS predicted orbits. As a result, we could get the mean errors of $1 \sim 1.6 \mathrm{~cm}$, standard deviation of $1 \sim 1.3 \mathrm{~cm}$ from one year of GPS data. This results were similar level to positioning accuracy using the IGS rapid orbits. Positioning errors of $>10 \mathrm{~cm}$ showed $44 \%$ of observed days of orbital anomalies. When the orbital anomalies of the predicted orbits were shown, maximum error was $1.7 \mathrm{~km}$, and maximum of mean errors was $308 \mathrm{~m}$. From this study, we conclude that check and consideration were necessary before using the IGS predicted orbits.

Key words : GPS, Predicted Orbits, Precise Point Positioning, Positioning Accuracy

\section{I. 서 론}

1980 년대 후반, 미국의 군사적 목적에 의해 개발 된 위성항법시스템(GNSS, Global Navigation Satellite System) 중 하나인 GPS(Global Positioning System)는 현대에 들어 항법, 측지/측량, 통신, 국방, 시각 등 다 양한 분야에서 활용되고 있다. GNSS를 이용한 위치 정보 산출 방법은 크게 상대측위(Relative Positioning) 와 단독측위(Point Positioning)로 나눌 수 있다. 상대
측위는 2 개 이상의 관측지점에서 수집한 데이터를 이용하여 상대 기선해석을 실시하는 기법으로, 공통 오차제거를 통해 위치 정확도를 향상시킨다. 단독측 위는 위치정보를 얻고자 하는 단일 관측지점의 관측 데이터만 이용하는 기법으로 IGS(International GNSS Service)에서 제공하는 궤도력과 오차보정 정보를 이 용하여 정확도를 향상시킨다. IGS에서 제공하는 GPS 궤도력에는 정밀궤도력(Precise Orbits), 신속궤도력 (Rapid Orbits), 초신속궤도력(Ultra-Rapid Orbits), 그리

\footnotetext{
* 한국항공우주연구원 위성항법팀(Satellite Navigation Team, Korea Aerospace Research Institute)

제1저자 (First Author) : 하지현

· 투고일자 : 2012년 10월 3일

심사(수정)일자 : 2012년 10월 4일 (수정일자: 2012년 10월 25일)

게재일자 : 2012년 10월 30일
} 
고 방송궤도력(Broadcast Ephemerides)이 있다[1]. 정 밀궤도력은 궤도 정확도가 $2.5 \mathrm{~cm}$ 이하로 4 가지 궤도 력 중 가장 정확한 편이지만 생성까지 12-18일의 가 장 긴 시간이 소요된다. 신속궤도력은 궤도 정확도가 정밀궤도력과 유사한 수준이지만, 생성까지 17-41시 간 정도 걸려 준실시간 혹은 실시간 응용에는 부적합 하다. 방송궤도력은 수신장비만 있으면 실시간으로 수집이 가능하나, 궤도 정확도가 $1 \mathrm{~m}$ 수준으로 다른 궤도력에 비해 현저히 낮은 편이다[2].

초신속궤도력은 생성되기까지 3-9시간이 소요되 며, 6시간 주기로 하루에 4회(UTC 기준 03시, 09시, 15시, 21시) 제공된다. 특히, 생성시간을 기준으로 이 전 24시간에 대한 궤도력 $(\mathrm{OH}$, Observed Half)뿐만 아 니라 이후 24시간에 대해 예측된 궤도력 $(\mathrm{PH}$, Predicted Half)이 포함하고 있어[2] 준실시간 응용에 적합하다. 예를 들어 2012년 1월 1일 $00 \mathrm{~h}(\mathrm{UTC})$ 에 생 성된 초신속궤도력은 2011년 12월 31일 00h부터 24h 까지 24시간의 $\mathrm{OH}$ 와 2012년 1월 1일 00h부터 24h까 지 24시간의 $\mathrm{PH}$ 가 포함되어 있다. 본 논문에서는 $\mathrm{PH}$ 를 예측궤도력이라고 칭한다. $\mathrm{OH}$ 의 궤도 정확도는 약 $3 \mathrm{~cm}$ 수준이며, 예측궤도력의 궤도 정확도는 약 $5 \mathrm{~cm}$ 수준이다. 따라서 실시간 혹은 준실시간 응용 시 초신속궤도력 (혹은 예측궤도력)을 이용할 경우 방송 궤도력에 비해 더욱 정확한 위치결정이 가능하다.

예측궤도력은 이전 시간에 수집된 관측데이터를 바탕으로 미래 시간에 대한 추정된 궤도를 기록한 것 이다. 따라서 궤도력이 생성된 이후에 위성 고장, 정 전, 유지/보수 등 예상치 못한 상황이 발생할 경우 이 에 대한 즉각적인 반영이 어려운 단점이 있다. 이러 한 점은 사용자에게는 오차요인으로 직결된다. 실제 로 2008년 1월 30일에 발생한 예측궤도력 이상현상 은 최대 수십m 수준의 사용자 위치오차를 유발하였 다[3]. 예측궤도력 이상현상에 대한 검출 방법은 크 게 3가지로, NANU(Current Notice Advisories to NAVSTAR Users)[4,5]를 활용하는 방법과 궤도 비교 방법, 그리고 궤도요소 별 시계열 모니터링 기법이 있다. 이 중 NANU와 궤도력 비교 기법을 병행할 경 우 $95 \%$ 수준의 이상검출이 가능하며[6], 궤도요소 모 니터링 기법을 추가할 경우, NANU와 궤도력 비교만 으로 검출되지 않았던 이상현상까지도 검출이 가능
하다[3]. 이 논문은 이상현상 검출에 관한 선행 연구 $[3,6]$ 의 후속으로써, 예측궤도력을 이용한 데이터 처 리 시 나타나는 위치 추정 결과의 정확도를 분석하 고, 예측궤도력 이상현상에 따른 오차를 분석하였다. 제 II장에서 분석대상 데이터와 분석 방법에 대해 기 술하고, 제 III장에서 위치오차 분석 결과, 그리고 IV 장에 결론을 맺는다.

\section{II. 데이터 및 분석 방법}

본 논문에서는 예측궤도력을 이용한 위치추정 정 확도와 궤도력 이상에 따른 위치오차 변화를 분석하 였다. 예측궤도력기반 위치추정 정밀도 분석을 위해 2010년 1월 1일부터 12월 31일까지 IGS에서 생성한 정밀궤도력, 신속궤도력, 초신속궤도력을 이용하였 다. 분석 대상 관측소로 국내 IGS 기준국인 DAEJ(대 전)과 $\mathrm{SUWN}$ (수원) 상시관측소를 이용하였으며, 데 이터 처리를 위하여 GIPSY-OASIS(GPS Inferred Positioning System-Orbit Analysis and Simulation Software)를 활용하였다. GIPSY-OASIS는 JPL(Jet Propulsion Laboratory)에서 개발한 고정밀 데이터 처 리 프로그램으로서, 정밀단독측위(PPP, Precise Point Positioning)기법을 사용할 수 있다. PPP는 IGS나 JPL 에서 궤도력과 함께 제공하는 위성시계오차 정보를 이용하여 관측소의 정밀 위치를 산출하는 기법이다 [7].

정밀궤도력과 신속궤도력은 궤도력과 함께 제공 되는 시계오차 해의 정밀도가 높은 반면, 초신속궤도 력은 시계오차 해의 정밀도가 낮아 원자시계가 연결 된 관측소의 시계를 기준으로 하여 나머지 관측소의 시계오차를 추정한다[8]. 이 논문에서는 Cesium 원자 시계가 연결된 DAEJ 관측소를 기준으로 SUWN 관측 소의 시계오차를 추정하였다. 데이터 처리 시 주요 오차요인인 안테나 위상중심 변동량 $(\mathrm{PCV}, \mathrm{Phase}$ Center Variations), 해양조석하중에 의한 지각변위 (OTL, Ocean Tidal Loading Displacements), 그리고 방 위각 방향으로의 수증기 변화량(Azimuthal Gradient) 을 보정하였다. GPS 위성 안테나와 지상 기준국의 안테나 $\mathrm{PCV}$ 보정을 위하여 절대보정(absolute 
표 1. 2010년 00h IGS 예측궤도력 이상 발생 현황 Table 1. Orbital anomalies of 00h IGS predicted orbits in 2010.

\begin{tabular}{|c|c|c|c|}
\hline DOY & PRN & DOY & PRN \\
\hline 014 & 24 & 265 & 19 \\
\hline 015 & 29 & 266 & 20 \\
\hline 020 & 30 & 267 & 20 \\
\hline 034 & 17 & 271 & 5 \\
\hline 040 & 26 & 274 & 30 \\
\hline 076 & 32 & 288 & 11 \\
\hline 127 & 9 & 321 & 27 \\
\hline 132 & 13 & 344 & 32 \\
\hline 169 & 25 & 348 & 32 \\
\hline 211 & 16 & 352 & 4 \\
\hline 216 & 26 & 357 & 25 \\
\hline 239 & 3 & 363 & 24 \\
\hline 255 & 21 & & \\
\hline
\end{tabular}

calibration) 기법을 적용하였으며, OTL 보정을 위하 여 FES2004 모델을 적용하였다. 임계고도각은 정밀 데이터 처리시 일반적으로 적용되는 $10^{\circ}$ 로 처리하였 다.

GIPSY-OASIS를 이용한 데이터 처리시, 정밀궤도 력과 신속궤도력은 해당일의 궤도력을 이용하였으 며, 초신속궤도력은 해당날짜와 다음날 $00 \mathrm{~h}$ 에 생성 된 궤도력을 각각 이용하였다. 즉, 해당날짜의 초신 속궤도력을 이용하여 24시간 $\mathrm{PH}$ 가 적용된 예측궤도 력 적용결과를 산출하였으며, 다음날의 초신속궤도 력을 이용하여 24시간 $\mathrm{OH}$ 가 적용된 초신속궤도력 결과를 산출하였다. 데이터 처리결과는 24 시간 간격 으로 평균 좌표를 결정한 후 연간 좌표시계열을 생성 하였으며, 정밀궤도력 결과를 참값으로 가정한 후 궤 도력에 따른 위치오차를 비교하였다. 예측궤도력 이 상현상에 의한 위치오차 분석을 위하여 GIPSY-OASIS의 Kinematic 기법을 이용하여 5 분 간격 으로 좌표를 추정하였으며, 초신속궤도력의 갱신주 기인 6시간을 기준으로 궤도력 이상 여부를 판단하 였다. 분석대상은 선행연구[6]에서 보고된 2010년 이 상현상 현황 중 $00 \mathrm{~h}$ 에 발생한 경우를 대상으로 하였 으며, 해당 날짜(DOY, Day of Year)와 위성을 표 1에 나타내었다.

\section{3-1 GPS 궤도력에 따른 위치추정 결과 비교}

예측궤도력을 이용한 위치추적 정확도를 분석하 기 위하여 정밀궤도력, 신속궤도력, 초신속궤도력을 이용하여 2010년 1년간 생성된 SUWN과 DAEJ의 관 측데이터를 처리하였다. 정밀궤도력을 이용한 결과 를 참값으로 신속궤도력, 초신속궤도력, 그리고 예측 궤도력의 오차를 산출하였으며, 그 결과를 그림 1 과 표 2에 에 나타냈다. 그림 1 의 가로축은 DOY이며, 세
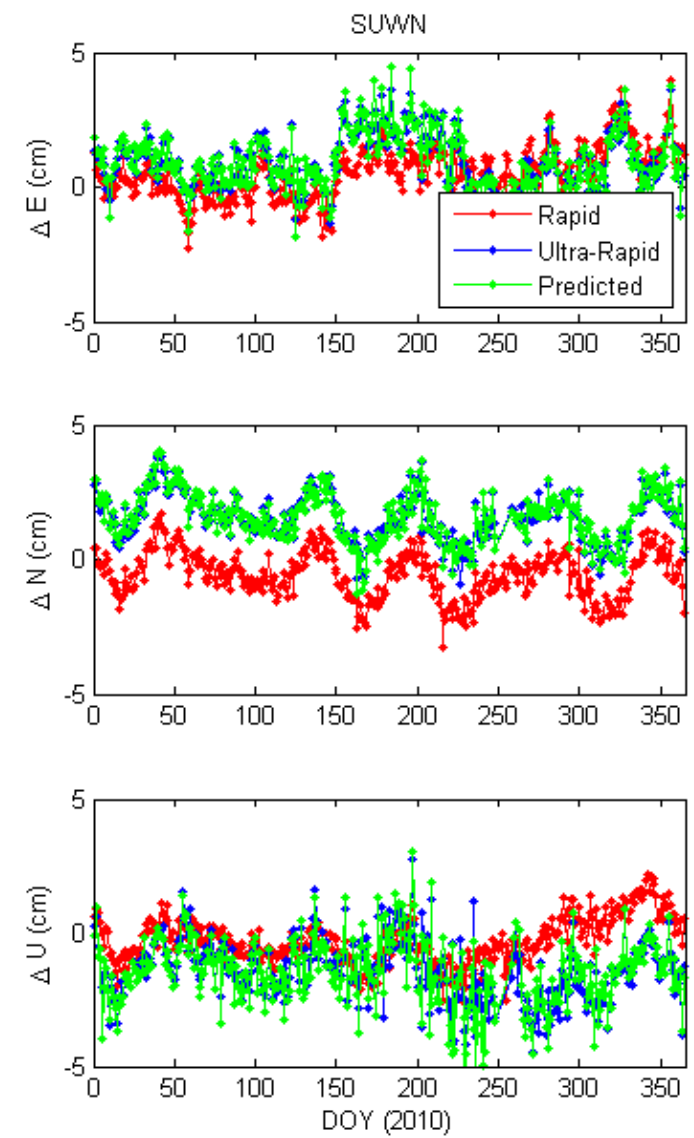

그림 1. 신속궤도력, 초신속궤도력, 예측궤도력을 이용한 좌표 오차 비교

Fig. 1. Comparison of ENV errors using rapid, ultra-rapid, and predicted orbits.

표 2. 평균오차(편향)과 표준편차

Table 2. Biases and standard deviation.

\begin{tabular}{|c|c|c|c|c|c|c|}
\hline \multirow{2}{*}{} & \multicolumn{3}{|c|}{ 평균 오차 $(\mathrm{cm})$} & \multicolumn{3}{|c|}{ 표준편차 $(\mathrm{cm})$} \\
\cline { 2 - 7 } & $\mathrm{E}$ & $\mathrm{N}$ & $\mathrm{U}$ & $\mathrm{E}$ & $\mathrm{N}$ & $\mathrm{U}$ \\
\hline 신속 & 0.5 & -0.6 & -0.3 & 1.0 & 0.9 & 0.9 \\
\hline 초신속 & 0.9 & 1.6 & -1.4 & 1.0 & 0.9 & 1.1 \\
\hline 예측 & 1.0 & 1.6 & -1.5 & 1.0 & 1.0 & 1.3 \\
\hline
\end{tabular}


로축은 궤도력에 따른 좌표 차이이다. 그림 1 의 좌표 오차는 선행연구[6]를 참고하여, 이상현상이 나타난 위성을 제외하고 산출한 결과이다. 궤도 이상현상에 대한 분석은 3-2절에서 다룬다.

그림 1을 보면 3개 궤도력의 결과가 서로 비슷한 경향을 보이며, 특히 초신속궤도력과 예측궤도력의 결과가 매우 유사한 것을 알 수 있다. 방향별 오차를 살펴보면, 동-서, 남-북, 수직 방향에서 모두 $\pm 5 \mathrm{~cm}$ 범 위에서 변했으나, 크기는 서로 다르지만 신속궤도력 결과와 초신속 혹은 예측궤도력의 결과 사이에 편향 이 존재하는 것을 알 수 있다. 신속궤도력과 예측궤 도력 사이의 편향은 남-북 방향으로 비교적 뚜렷하게 나타났다. 이는 표 2의 평균오차에서도 확인할 수 있 는데, 남-북 방향을 제외하면 신속, 초신속, 예측궤도 력 오차가 모두 양의 편향을 나타낸 반면, 남-북 방향 의 경우 신속궤도력은 음의 편향을, 초신속궤도력과 예측궤도력은 양의 편향을 보임으로써 상호간 편향 이 뚜렷하게 나타난 것이다. 신속궤도력과 초신속궤 도력의 편향은 $2.2 \mathrm{~cm}$ 이다.

표 2의 평균오차를 살펴보면, 신속궤도력에 비해 초신속궤도력과 예측궤도력이 $1 \mathrm{~cm}$ 정도 높게 나타났 으나, 초신속궤도력과 예측궤도력 사이의 차이는 거 의 없음을 알 수 있다. 표준편차는 신속궤도력, 초신 속궤도력, 그리고 예측궤도력이 서로 유사한 수준으 로 나타났다. 이는 예측궤도력을 이용하여도 신속궤 도력 대비 $1 \mathrm{~cm}$ 수준의 오차를 보이며 비교적 정확한 위치결정이 가능하며, 정밀도 면에서도 신속궤도력 과 유사한 수준을 달성할 수 있음을 의미한다.

3-2 예측궤도력 궤도이상 검출 여부에 따른 위 치추정 정확도 분석

서론에서 언급한 바와 같이, 예측궤도력은 궤도 이상이 나타날 가능성이 있다. 궤도이상은 좌표오차 로 직결되기 때문에 신속궤도력과 유사한 수준의 정 확도/정밀도를 달성하고 유지하기 위해서는 이점을 반드시 보완해야 한다. I 절에서 기술한 2008년 1월 30 일을 예로 들면, 1 월 30 일 $00 \mathrm{~h}$ 예측궤도력에는 궤 도이상이 포함되어 있었으며, 이로 인하여 사용자에 게는 수십 $\mathrm{m}$ 수준의 위치오차가 유발되었다. 그림 2 에 해당 날의 정밀궤도력과 예측궤도력의 차이를 나

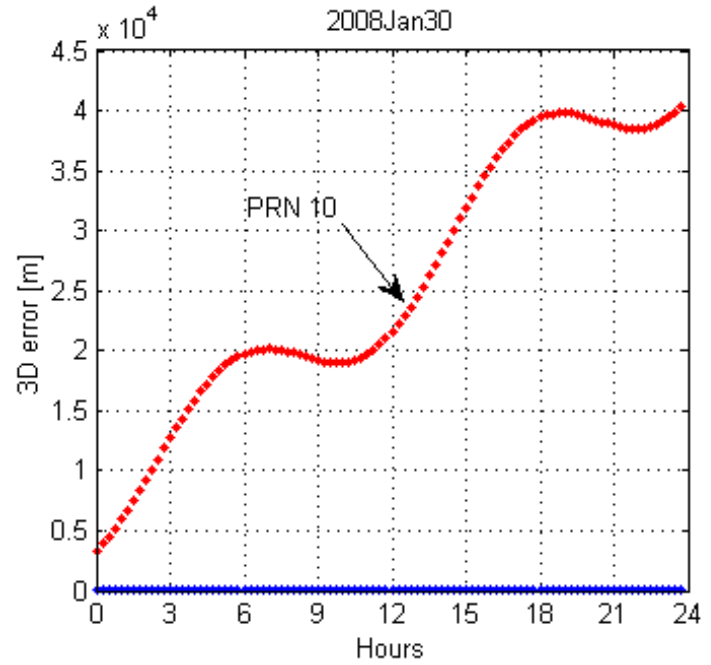

그림 2. 2008년 1월 30일 예측궤도력 3D 좌표 오차[3]

Fig. 2. 3D error of predicted orbits on Jan. 30, 2008[3].

타내었다.

그림 2를 보면, PRN 10번 위성이 정밀궤도력에 비 해 수백 $\mathrm{km}$ 수준의 오차가 발생한 것을 볼 수 있다. 이는 위성 유지보수로 인하여 속도조정이 이루어진 경우로, 예측궤도력에는 이 상황이 반영되지 않은 것 이다. 그림 3 에 2008년 1월 1 일부터 50 일간 SUWN 관 측소의 좌표 모니터링 결과를 나타내었다. 그림 3 의 가로축은 시간(DOY)이며, 세로축은 좌표오차이다. 좌표오차는 정밀궤도력을 이용하여 산출한 좌표를 참값으로 가정한 후, 예측궤도력 결과와의 차이를 나 타낸 것이다. 그림 3(a)-(c)는 예측궤도력 이상현상을 제거하지 않은 결과이며, 그림 3(d)-(f)는 예측궤도력 에서 30 일의 PRN 10 번 위성을 제외하고 자료처리한 결과이다.

그림 3(a)-(c)를 보면, 30 일에 동-서, 남-북, 수직방 향으로 뚜렷한 좌표 이상이 관측되었으며, 동-서 방 향으로 최대 $982.0 \mathrm{~cm}$, 남-북 방향으로 최대 $-104.0 \mathrm{~cm}$, 그리고 수직방향으로 최대 $12.2 \mathrm{~cm}$ 의 오차가 나타났 다. PRN10번 위성의 궤도력을 제거한 후에는 동-서 방향으로 $-7.3 \mathrm{~cm}$, 남-북 방향으로 $1.8 \mathrm{~cm}$, 그리고 수직 방향으로 $0.8 \mathrm{~cm}$ 의 오차가 관측되어, 30 일 평균 오차 와 유사한 결과가 나타났다. 30 일 평균 오차는 동-서 방향 $-7.2 \mathrm{~cm}$, 남-북 방향 $1.6 \mathrm{~cm}$, 그리고 수직방향 $1.0 \mathrm{~cm}$ 이다. 이와 같이 예측궤도력 이상은 사용자 위 치오차와 직결되며, 하나의 위성에 대한 궤도이상이 

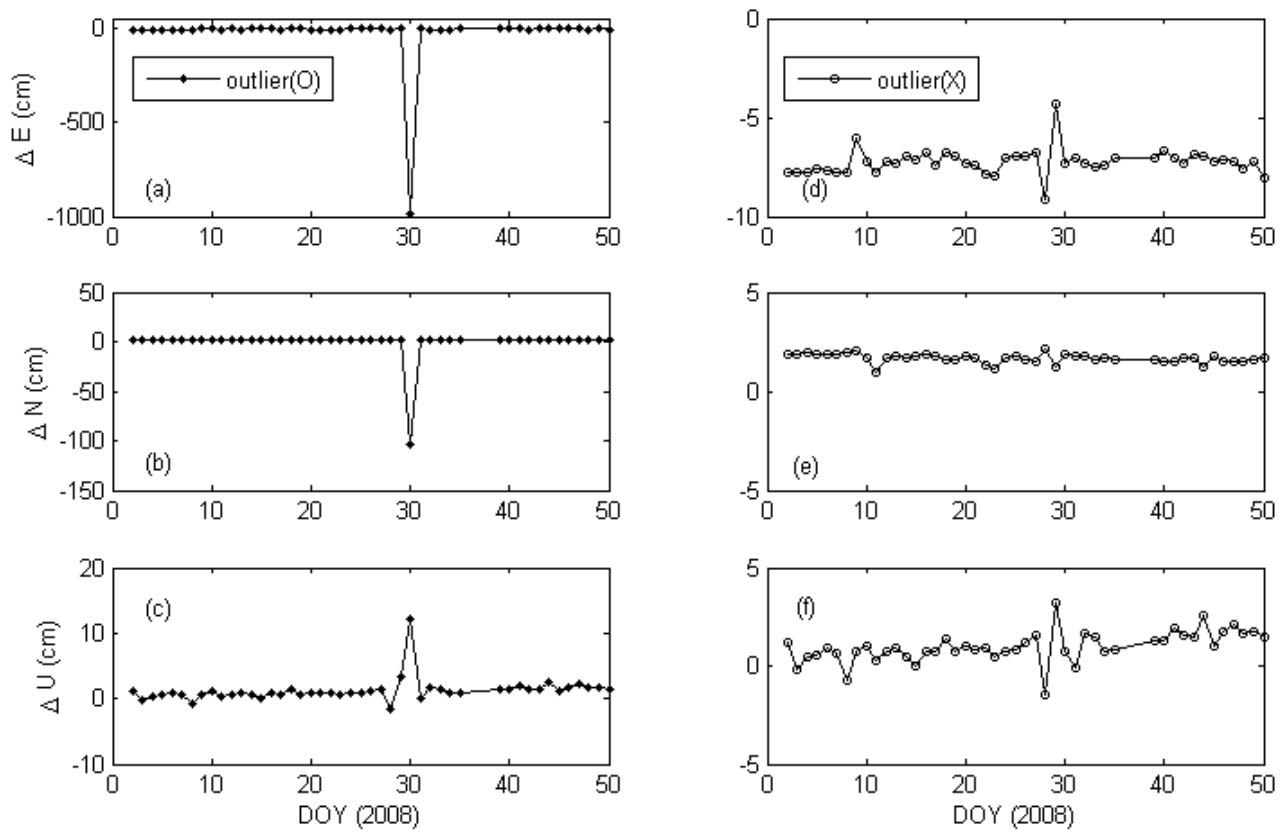

그림 3. 2008년 1월 30일 예측궤도력 이상점 포함여부에 따른 SUWN 관측소 좌표 오차

Fig. 3. Position errors of SUWN station with/without orbital anomalies of IGS predicted orbits on 30 Jan., 2008.

사용자에게는 수m 수준의 위치오차로 나타날 수 있 다.

이 논문에서는 선행연구[6]에서 제시한 2010년의 예측궤도력 이상현상을 활용하여, 다양한 경우에서 궤도 이상 현상에 의한 좌표 오차를 분석하였다. 일 반적으로 예측궤도력은 정밀궤도력에 대하여 6시간 이내에 평균 $5 \sim 10 \mathrm{~cm}$, 최대 $1 \mathrm{~m}$ 수준의 3 차원 좌표 오 차가 나타난다 $[9,10]$. 따라서 선행연구[6]에서는 정밀 궤도력과 예측궤도력을 비교하여 생성시간으로부터 6시간이내에 $1 \mathrm{~m}$ 이상의 오차가 발생한 경우를 궤도 이상으로 판단하였다. 이 논문에서도 선행연구의 결 과에 따라 정밀궤도력을 기준으로 $1 \mathrm{~m}$ 이상 오차가 발생한 경우를 대상으로 좌표 오차에 미치는 영향을 평가하였다.

궤도이상에 의한 좌표 오차를 보다 자세하게 분석 하기 위하여 GIPSY-OASIS Kinematic기법을 적용하 여 5 분 간격으로 좌표를 결정하였다. 참값에 대한 좌 표오차를 그림 4에 나타내었다. 그림 4의 좌표오차는 표 1에 나타낸 2010년 00h IGS 예측궤도력 이상현상 이 발생한 25 일의 결과를 날짜에 상관없이 시간에 따 라 도식한 것이다. 그림 4 의 가로축은 시간이며, 세로 축은 SUWN관측소의 기준좌표(위도: $37.27551479^{\circ} \mathrm{N}$,
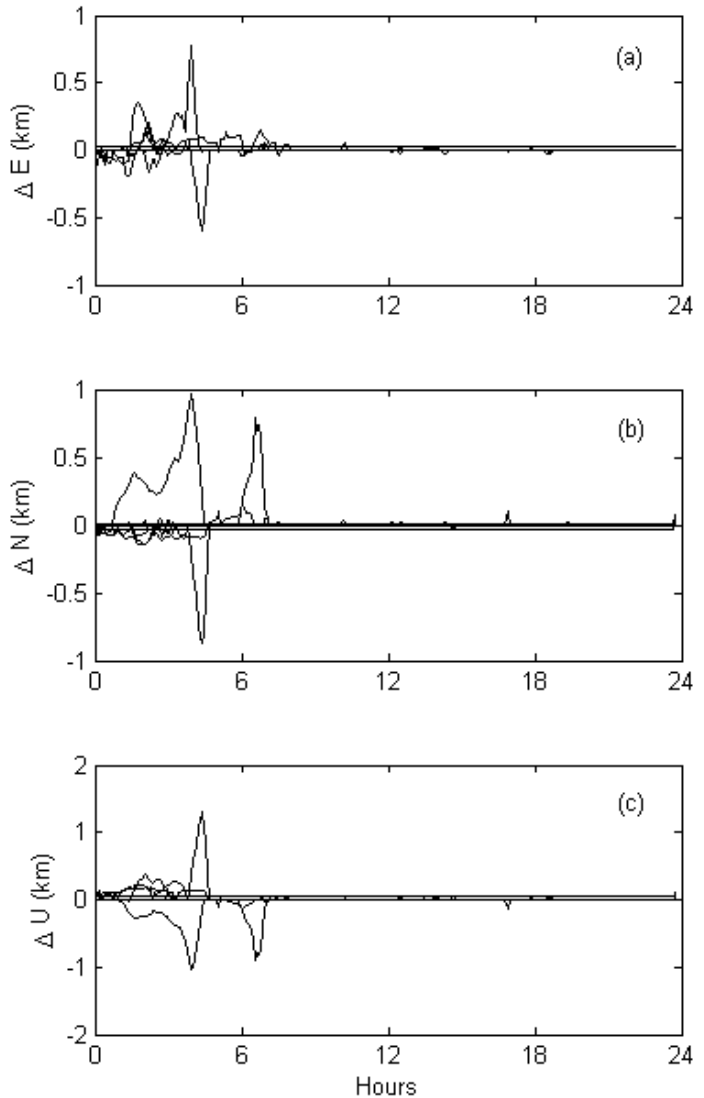

그림 4. 궤도 이상 현상에 의한 좌표 오차

Fig. 4. Position errors due to orbital anomalies. 
경도: $127.05423993^{\circ} \mathrm{E}$, 고도: $84.82 \mathrm{~m}$ )에 대한 좌표 차 이이다. 기준좌표는 24 시간 자료처리를 통해 산출하 였다. 그림 4 를 보면 크기의 차이는 있지만, 25 일 동 안 동-서, 남-북, 수직방향에서 모두 오차가 관측되었 으며, 수직방향으로 최대 $1.5 \mathrm{~km}$ 수준의 오차가 나타 난 것을 알 수 있다. 동-서, 남-북 방향으로는 $\pm 1 \mathrm{~km}$ 범위에서 오차가 관측되었으며, 수직방향으로는 수
평방향보다 비교적 큰 $\pm 1.5 \mathrm{~km}$ 범위에서 나타났다. $06 \mathrm{~h}$ 이후에 나타난 오차는 6 시간 이후에도 예측궤도 력에서 궤도이상이 포함되어 있기 때문이다.

각 날짜별로 최대 오차를 표 3 에 나타내었다. 표 3 의 시간은 최대오차가 나타난 시간이며, 평균오차는 6시간 평균을 의미한다. $3 \mathrm{D}$ 최대오차는 시간에 무관 하게 $\mathrm{E}, \mathrm{N}, \mathrm{U}$ 방향의 최대 오차를 3 차원 방향으로 산

표 3. IGS 예측궤도력 이상에 의한 최대오차와 평균 오차

Table 3. Maximum and mean errors due to orbital anomalies of IGS predicted orbits.

\begin{tabular}{|c|c|c|c|c|c|c|c|c|c|c|c|}
\hline \multirow{2}{*}{$\begin{array}{l}\mathrm{D} \\
\mathrm{O} \\
\mathrm{Y}\end{array}$} & \multicolumn{3}{|c|}{$\mathrm{E}$} & \multicolumn{3}{|c|}{$\mathrm{N}$} & \multicolumn{3}{|c|}{$\mathrm{U}$} & \multicolumn{2}{|c|}{$3 \mathrm{D}$} \\
\hline & 시간 & $\begin{array}{l}\text { 최대 } \\
\text { 오차 } \\
\text { (m) }\end{array}$ & $\begin{array}{l}\text { 평균 } \\
\text { 오차 } \\
\text { (m) }\end{array}$ & 시간 & $\begin{array}{l}\text { 최대 } \\
\text { 오차 } \\
\text { (m) }\end{array}$ & $\begin{array}{l}\text { 평균 } \\
\text { 오차 } \\
\text { (m) }\end{array}$ & 시간 & $\begin{array}{l}\text { 최대 } \\
\text { 오차 } \\
\text { (m) }\end{array}$ & $\begin{array}{l}\text { 평균 } \\
\text { 오차 } \\
\text { (m) }\end{array}$ & $\begin{array}{l}\text { 최대 } \\
\text { 오차 } \\
\text { (m) }\end{array}$ & $\begin{array}{l}\text { 평균 } \\
\text { 오차 } \\
(\mathrm{m})\end{array}$ \\
\hline 014 & 5.96 & -0.03 & -0.02 & 2.71 & 0.02 & 0.01 & 2.71 & -0.03 & -0.02 & 0.05 & 0.03 \\
\hline 015 & 5.96 & -36.95 & -0.55 & 5.96 & 125.97 & 1.72 & 5.96 & -107.53 & -1.47 & 169.69 & 2.33 \\
\hline 020 & 5.96 & -0.04 & -0.02 & 2.29 & 0.05 & 0.03 & 2.29 & -0.06 & -0.03 & 0.08 & 0.04 \\
\hline 034 & 3.96 & 781.82 & 42.77 & 3.96 & 962.17 & 238.50 & 3.96 & $-1,033.08$ & -191.24 & $1,613.78$ & 308.68 \\
\hline 040 & 4.63 & -0.04 & -0.02 & 4.88 & 0.06 & 0.02 & 4.88 & -0.07 & -0.03 & 0.10 & 0.04 \\
\hline 076 & 4.54 & -0.04 & -0.03 & 2.38 & 0.05 & 0.02 & 2.38 & -0.07 & -0.03 & 0.10 & 0.05 \\
\hline 127 & 3.46 & -0.03 & -0.03 & 0 & 0.03 & 0.01 & 0.00 & -0.04 & -0.01 & 0.06 & 0.03 \\
\hline 132 & 4.38 & -0.04 & -0.04 & 0 & 0.02 & 0.01 & 0.00 & -0.03 & -0.01 & 0.05 & 0.04 \\
\hline 169 & 3.96 & -0.05 & -0.04 & 3.96 & -0.02 & 0.00 & 3.96 & 0.02 & 0.00 & 0.06 & 0.04 \\
\hline 211 & 2.79 & -1.01 & -0.04 & 2.79 & 1.07 & 0.00 & 2.79 & -1.40 & -0.01 & 2.03 & 0.04 \\
\hline 216 & 0.79 & -0.05 & -0.04 & 3.79 & -0.03 & -0.02 & 3.79 & 0.04 & 0.03 & 0.08 & 0.05 \\
\hline 239 & 1.63 & -0.05 & -0.03 & 0.46 & 0.03 & -0.01 & 0.46 & -0.04 & 0.01 & 0.07 & 0.03 \\
\hline 255 & 3.38 & 28.79 & 28.76 & 5.96 & -35.18 & -35.11 & 5.96 & 46.22 & 46.13 & 64.83 & 64.71 \\
\hline 265 & 0.38 & -0.06 & -0.03 & 0 & 0.04 & -0.01 & 0.00 & -0.05 & 0.01 & 0.09 & 0.03 \\
\hline 266 & 2.96 & -37.27 & -0.91 & 3.04 & -50.60 & -1.31 & 3.04 & 100.89 & 2.68 & 118.87 & 3.11 \\
\hline 267 & 0.21 & -0.05 & -0.02 & 4.04 & -0.03 & -0.01 & 4.04 & 0.04 & 0.02 & 0.07 & 0.03 \\
\hline 271 & 4.38 & -596.56 & -26.64 & 4.38 & -877.64 & -109.00 & 4.38 & $1,316.95$ & 202.08 & $1,691.30$ & 231.14 \\
\hline 274 & 1.79 & 351.43 & 74.97 & 1.96 & -147.48 & -42.76 & 1.96 & 222.93 & 74.93 & 441.53 & 114.30 \\
\hline 288 & 1.29 & -195.70 & -12.81 & 2.04 & -147.60 & -24.56 & 2.04 & 373.27 & 92.54 & 446.56 & 96.59 \\
\hline 321 & 5.63 & -0.03 & -0.02 & 5.63 & 0.02 & 0.00 & 5.63 & -0.02 & 0.00 & 0.04 & 0.02 \\
\hline 344 & 5.54 & -0.05 & -0.03 & 3.71 & 0.02 & 0.00 & 3.71 & -0.03 & -0.01 & 0.06 & 0.03 \\
\hline 348 & 2.04 & -16.57 & -0.46 & 2.04 & 27.49 & 0.75 & 1.96 & 6.10 & 0.14 & 32.67 & 0.89 \\
\hline 352 & 4.88 & -0.06 & -0.04 & 5.96 & -0.03 & 0.00 & 5.96 & 0.04 & 0.00 & 0.07 & 0.04 \\
\hline 357 & 2.63 & -38.85 & -0.63 & 2.63 & 50.96 & 1.16 & 2.63 & -8.88 & -0.12 & 64.69 & 1.33 \\
\hline 363 & 3.13 & -9.72 & -0.06 & 3.21 & 18.55 & 0.36 & 3.13 & 28.51 & 0.57 & 35.37 & 0.68 \\
\hline
\end{tabular}


출한 것이다. 좌표오차의 단위는 $\mathrm{m}$ 이다.

표 3 을 보면, 최대오차가 수 $\mathrm{cm}$ 에서 $1 \mathrm{~km}$ 이상까지 다양한 크기로 관측되었다. 2010년 1년동안 SUWN 관측소는 궤도이상이 포함되지 않았을 때, $\pm 5 \mathrm{~cm}$ 수 준에서 좌표오차가 나타났다(그림 1). 따라서 표 3 의 결과 중 $\pm 10 \mathrm{~cm}$ 이상 발생하는 오차는 궤도력 이상에 의해 발생 가능한 오차라고 가정할 수 있으며, DOY 015, 034, 211, 255, 266, 267, 271, 274, 288, 348, 357, 363 이 이에 해당한다(표 3에 회색으로 표시). 이는 전 체 분석기간 중 $44 \%$ 로 절반 가까이에 해당한다. 특 히, 최대오차가 동-서 방향으로 -596.56 781.82m, 남북 방향으로 -877.64 962.14m, 수직 방향으로 $-1,033.08 \sim 1,316.95 \mathrm{~m}$ 로 나타났으며, 이는 궤도이상에 대한 보정이 이루어지지 않을 경우 정밀측위가 어려 운 수준이다.

11 일 중 가장 큰 오차가 나타난 날은 DOY 034일 과 DOY 271일이며, 방향별 최대오차가 관측된 시간 도 일치한다. DOY 034일과 DOY 271일 뿐만 아니라, DOY 255 일을 제외하면 최대오차가 나타난 시간이 동일하거나 거의 비슷하다. 이는 해당 위성이 유지보 수 등의 이벤트가 발생하였을 때 모든 방향으로 영향 을 미치는 것을 의미하며, 방향별로 살펴보면 대부분 수평방향보다 수직방향으로 다소 높은 오차가 나타 나는 것을 알 수 있다. $\pm 10 \mathrm{~cm}$ 이상오차가 발생한 날 중 DOY 211을 제외하면 6시간 평균오차 역시 $\pm 10 \mathrm{~cm}$ 이상 나타났다. 즉, 하나의 위성에서 궤도이상이 나 타난 경우 전체 분석기간 동안에도 영향을 미치는 것
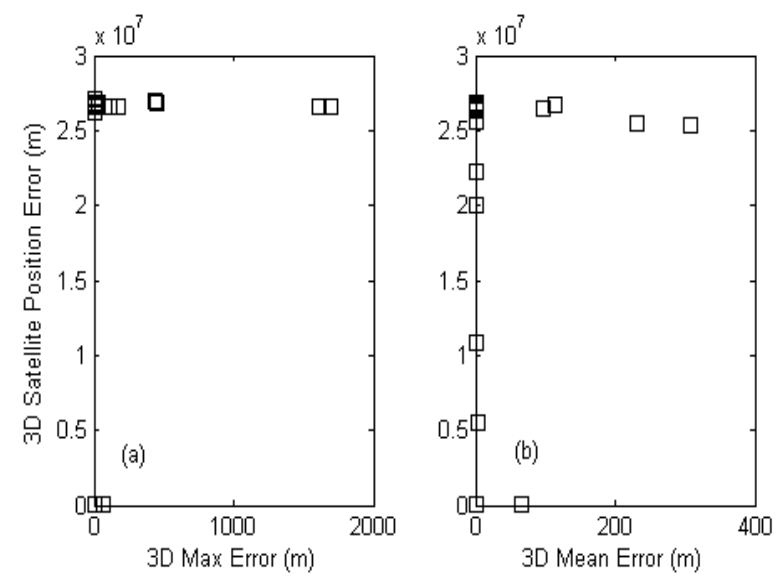

그림 5. 궤도이상과 최대, 평균오차 비교

Fig. 5. Comparison between orbital anomalies and maximum and mean errors.
이다. 이는 그림 3 의 결과와도 일맥상통한다.

좌표 오차와 궤도이상과의 상관관계 분석 결과를 그림 5 에 나타내었다. 그림 5의 가로축은 SUWN 관 측소의 (a)최대 좌표오차와 (b)평균오차이며, 세로축 은 최대, 평균 궤도오차이다.

그림 5 를 보면 궤도력 이상이 작을 경우 추정된 기 준국의 좌표 오차또한 작지만, 위성 궤도력 이상현상 이 $25,000 \mathrm{~km}$ 이상 나타날 경우에는 최대 $1.7 \mathrm{~km}, 6$ 시 간 평균 최대 $308 \mathrm{~m}$ 수준의 오차가 나타날 수 있다는 것을 의미한다. 단, 이 결과는 GIPSY-OASIS를 이용 하여 산출된 오차이며, 사용자의 프로그램에 따라 결 과는 다르게 나타날 수 있다. 선행연구[6]에 의하면 예측궤도력 이상현상은 년간 생산되는 예측궤도력 중 $13 \%$ 수준에서 발생한다. 이 중 $44 \%$ 정도가 궤도 이상에 의한 좌표오차를 유발할 가능성이 있으며, 최 대 $1.5 \mathrm{~km}$ 수준까지 나타날 수 있음을 알 수 있었다. 이는 사용자가 예측궤도력을 사용함에 있어 궤도이 상을 사전에 감지하지 못할 경우 정밀측위가 어려운 수준임을 의미한다. 따라서 예측궤도력 사용에 앞서, 사용자는 반드시 예측궤도력 이상 검출을 선행해야 한다.

\section{$\mathrm{IV}$. 결 론}

본 논문에서는 예측궤도력을 사용했을 때 나타나 는 위치추정 정확도와 예측궤도력 이상현상에 따른 위치추정 오차를 분석하였다. 예측궤도력 위치 추정 정확도 분석을 위하여 정밀궤도력, 신속궤도력, 그리 고 초신속궤도력을 이용하였으며, 특히 초신속궤도 력은 해당날짜와 다음날짜의 $00 \mathrm{~h}$ 에 생성된 궤도력을 사용하여 예측궤도력과 $\mathrm{OH}$ 를 각각 적용한 결과를 도출하였다. 분석대상이 된 관측소는 국내 IGS 상시 관측소인 SUWN과 DAEJ이었으며, 2010년 1년간 수 집된 데이터를 이용하였다. 그 결과 예측궤도력을 이 용할 경우 정밀궤도력을 기준으로 평균 $2 \mathrm{~cm}$ 이내의 오차를 보였으며, 표준편차 $1.5 \mathrm{~cm}$ 수준으로 신속궤도 력이나 초신속궤도력과 비슷한 수준을 달성할 수 있 었다. 다음으로 예측궤도력 이상현상에 의한 좌표오 차를 분석하기 위하여 2010년 00h 예측궤도력을 대 
상으로 GIPSY Kinematic 기법을 적용하여 5 분 간격 으로 좌표를 추정하였다. 그 결과 전체 분석대상 기 간 중 $44 \%$ 에 해당하는 날짜에서 $10 \mathrm{~cm}$ 이상의 좌표오 차가 나타났으며, 위성궤도력 이상현상이 $25,000 \mathrm{~km}$ 이상인 경우에는 최대 $1.7 \mathrm{~km}$, 평균오차 역시, 최대 $308 \mathrm{~m}$ 수준으로 나타났다. 따라서 보다 정확한 위치 결과 도출을 위하여, 예측궤도력을 사용할 때에는 사 전에 궤도력 이상현상에 대한 점검이 필요할 것으로 판단된다.

\section{감사의 글}

본 연구는 기초기술연구회의 "재난예방 및 국민안 전제고를 위한 위성기반 위치추적기술 연구" 과제의 일환으로 수행되었으며 지원에 감사드립니다.

\section{참 고 문 헌}

[1] http://igscb.jpl.nasa.gov

[2] http://igscb.jpl.nasa.gov/components/prods.html

[3] 하지현, 준실시간 3 차원 수증기 분포도 결정을 위한 고정 밀 GPS 자료처리 전략, 박사학위논문, 인하대학교, 162pp, 2009, 2.

[4] http://www.navcen.uscg.gov

[5] http://www.schriever.af.mil/GPS

[6] 하지현, 허문범, 남기욱, "GPS기반 준실시간 위치추적 을 위한 IGS 예측궤도력 이상 검출", 한국항행학회지 제 15권, 제 6호, pp. 953-961, 2011, 12.

[7] F. H. Webb, and J. F. Zumberge, An introduction to the GIPSY/OASIS-II, JPL Pulb., Pasadena, CA, July 1993. [8] 박관동, 조정호, 하지현, 임형철, "초신속궤도력을 이용 한 신속한 고정밀 GPS 데이터 처리", 한국측량학회지, 제 21권, 제 4호, pp. 309-316, 2003, 12.

[9] L. P. Kruse, B. Sierk, T. Springer, and M. Cocard, "GPS-meteorology: Impact of predicted orbits on precipitable water estimates", Geophysical Research Letters, Vol. 26, No. 14, pp. 2045-2048, July 1999.

[10] 김혜인, 위성측위 가용성 및 정확도 항상 평가를
위한 통합 GNSS 시뮬레이터 개발, 석사학위논문, 인하대학교, 103pp. 2009, 2.

\section{하 지 현 (河知賢)}

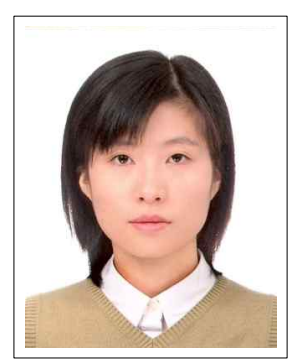

2003년 2월 : 충북대학교 천문우주학과 (이학사)

2005년 2월 : 충북대학교/한국천문 연구원 천문우주/우주측지전공 (이학석사)

2009년 2월 : 인하대학교 지리정보 공학과(공학박사)

2010년 2월 현재 : 한국항공우주연구원 선임연구원 관심분야 : GNSS, 위성항법, 정밀항법 등

\section{허 문 범 (許文範)}

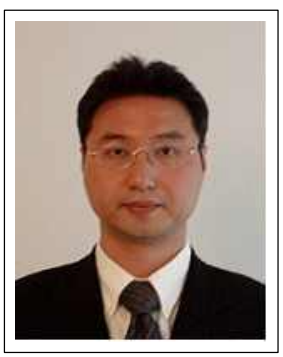

선임연구원

\section{남 기 욱 (南基旭)}

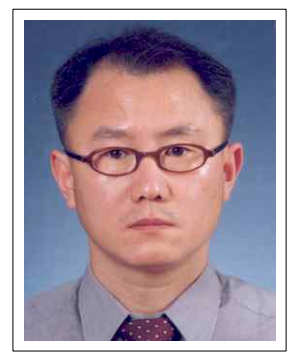

1983년 2월 : 한국항공대학교 항공 운항학과(공학사)

1988년 2월 : 한국항공대학교 항공 운항학과(공학석사)

1996년 6월 : Cranfield Univ. 항공공학과 (공학박사)

1988년 7월 1989년 7월 : 한국과학기술

연구원 연구원

1989년 8월 1992년 7월 : 한국항공우주연구원 선임연구원 1996년 12월 현재 : 항공우주연구원 책임연구원 관심분야 : GNSS, 위성항법, 항행시스템 등 